\title{
Free radical activity and left ventricular function after thrombolysis for acute infarction
}

Simon W Davies, Kulasegaram Ranjadayalan, David G Wickens, Thomas L Dormandy, Velaitham Umachandran, Adam D Timmis

Cardiac Department, London Chest Hospital, London $S$ W Davies

A D Timmis

Department of

Cardiology, Newham

General Hospital,

London

K Ranjadayalan

V Umachandran

Department of

Biochemistry,

Whittington Hospital,

London

D G Wickens

T L Dormandy

Correspondence to

Dr S W Davies, Cardiac

Department, London Ches

Hospital, Bonner Road,

London E2 9JX.

Accepted for publication

27 August 1992.

\begin{abstract}
Background-Experimental data suggest that reperfusion injury involving free radicals contributes to the impairment of left ventricular function after successful thrombolysis.
\end{abstract}

Methods-In 72 patients presenting with acute myocardial infarction, markers of free radical activity were measured before streptokinase and two hours later. Thiobarbituric acid reactive material (TBA-RM) reflects lipid peroxidation by free radicals, and the concentration of plasma total thiols (34 patients) reflects oxidative stress. Coronary arteriography was performed at 18-72 hours after thrombolysis to determine coronary patency, and left ventricular function was assessed by ventriculography and from QRS scoring of the electrocardiogram.

Results-The infarct related artery was patent (Thrombolysis In Myocardial Infarction Trial grade 2 or better) in 60 $(83 \%)$ and occluded in 12 . In the 60 with a patent artery, the concentration of TBA-RM increased after streptokinase by (mean (SD)) $9.2 \quad(14.0) \mathrm{nmol} / \mathrm{g}$ albumin, whereas in the 12 with an occluded artery TBA-RM decreased by $7.0(11.3) \mathrm{nmol} / \mathrm{g}$ albumin $(\mathrm{p}<0.01$ between groups). In those with a patent artery the rise in TBA-RM associated with thrombolysis correlated with left ventricular ejection fraction $(R=-0.41$, p $<0.002)$, and with the QRS score ( $R$ $=+0.38, p=0.003)$. Plasma total thiol concentrations decreased by $12.7(31 \cdot 1)$ $\mu \mathrm{mol} / \mathrm{l}$ in those with a patent artery, and this decrease associated with thrombolysis correlated with left ventricular ejection fraction $(R=+0.39, p<0.02)$ but
Global left ventricular ejection fraction (\%) in trials of intravenous thrombolysis for acute myocardial infarction

\begin{tabular}{|c|c|c|c|c|}
\hline \multirow[b]{2}{*}{ Trials } & \multicolumn{2}{|c|}{ Ejection fraction mean (SD) (\%) } & \multirow{2}{*}{$\begin{array}{l}\text { Total } \\
\text { No }\end{array}$} & \multirow{2}{*}{$\begin{array}{l}\text { Time } \\
\text { to angiogram } \\
\text { (days) }\end{array}$} \\
\hline & Control & Thrombolysis & & \\
\hline \multicolumn{5}{|c|}{ Streptokinase } \\
\hline $\begin{array}{l}\text { White et al: New Zealand } \\
\text { Scheiber et al }{ }^{7} \\
\text { Kennedy et al: Western Washington } \\
\text { Olson et al }{ }^{9} \\
\text { ISAM }^{10}\end{array}$ & $\begin{array}{l}53(14) \\
42(7) \\
51(13) \\
50(13)\end{array}$ & $\begin{array}{l}59(11) \\
47(10) \\
54(12) \\
53(16)\end{array}$ & $\begin{array}{r}155 \\
24 \\
235 \\
46\end{array}$ & $\begin{array}{r}21 \\
7-28 \\
3-21 \\
14-21\end{array}$ \\
\hline $\begin{array}{l}<3 \mathrm{~h} \\
3-6 \mathrm{~h}\end{array}$ & $\begin{array}{l}53(14) \\
54(14)\end{array}$ & $\begin{array}{l}57(15) \\
56(13)\end{array}$ & $\begin{array}{l}611 \\
230\end{array}$ & $\begin{array}{l}21-28 \\
21-28\end{array}$ \\
\hline \multicolumn{5}{|c|}{ Alteplase (rt-PA) } \\
\hline $\begin{array}{l}\text { O'Rourke et al: Sydney/Aukland }{ }^{11} \\
\text { Guerci et al }{ }^{12} \\
\text { Australian Coronary Group }{ }^{13} \\
\text { European Study Group }\end{array}$ & $\begin{array}{l}54(14) \\
46(4) \\
52(15) \\
49(11)\end{array}$ & $\begin{array}{l}61(13) \\
53(2) \\
58(16) \\
51(11)\end{array}$ & $\begin{array}{l}145 \\
138 \\
103 \\
721\end{array}$ & $\begin{array}{l}21 \\
10 \\
5-7 \\
7-21\end{array}$ \\
\hline
\end{tabular}

not with the QRS score $(R=-0 \cdot 2, N S)$.

Conclusions-These findings suggest that reperfusion injury mediated by free radicals may be of clinical importance in humans.

(Br Heart $\mathcal{f} 1993 ; 69: 114-120)$

Thrombolytic treatment of acute myocardial infarction is effective in restoring coronary patency and in reducing mortality. ${ }^{1-4}$ Improvements in left ventricular function however, have been difficult to show, ${ }^{5}$ and in many trials of thrombolytic agents the improvement has been disappointingly small (table). Furthermore, regional left ventricular dysfunction is common after successful thrombolysis.

In animal models the earlier reperfusion occurs the smaller the extent of infarction..$^{15-17}$ This regional dysfunction must partly reflect damage accrued during the ischaemic period. Experimental evidence however suggests that there is further damage at the time of reperfusion-so-called reperfusion injury. ${ }^{18}{ }^{19}$ If reperfusion injury occurs in humans then attempts to limit its effects could maximise the benefits of early thrombolysis.

The mechanism of reperfusion injury is thought to involve oxygen derived free radicals. ${ }^{20-23}$ We have already shown an increase in markers of free radical activity associated with successful thrombolysis in patients receiving streptokinase for acute myocardial infarction. $^{24}$ In the present study we have examined the relation between markers of oxidative stress and of free radical activity at the time of thrombolysis and subsequent left ventricular function, to assess the importance of reperfusion injury in the clinical setting.

\section{Patients and methods}

PATIENTS

We studied 72 consecutive patients receiving thrombolytic treatment for acute myocardial infarction at a district general hospital. Patients gave a history of typical cardiac chest pain for at least 30 minutes, with ST segment elevation of at least $1.5 \mathrm{~mm}$ in two or more topographically related leads, with no contraindication to thrombolysis. Subsequently all were found to have peak blood concentrations of creatine kinase greater than twice the upper limit of normal in our laboratory. Patients with previous myocardial infarction were included.

There were 30 women and 42 men, aged 

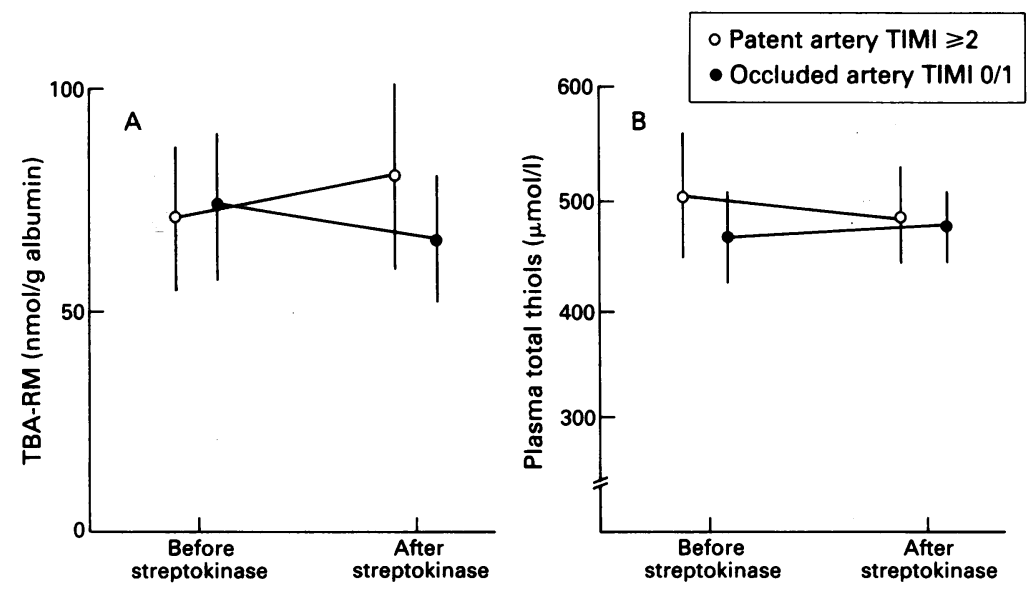

Figure 1 Peripheral blood concentrations of free radical markers before and after thrombolytic treatment: (A) TBA-RM; (B) plasma total thiol concentrations.

34-80 years (mean age 61 ). All received intravenous infusion of streptokinase ( 1.5 mega units over one hour) starting between one and seven hours after the onset of continued severe chest pain (mean interval four hours), and oral aspirin $(150 \mathrm{mg})$. Subsequently patients were infused with heparin for 24 hours and continued to take aspirin $(150 \mathrm{mg}$ a day) indefinitely.
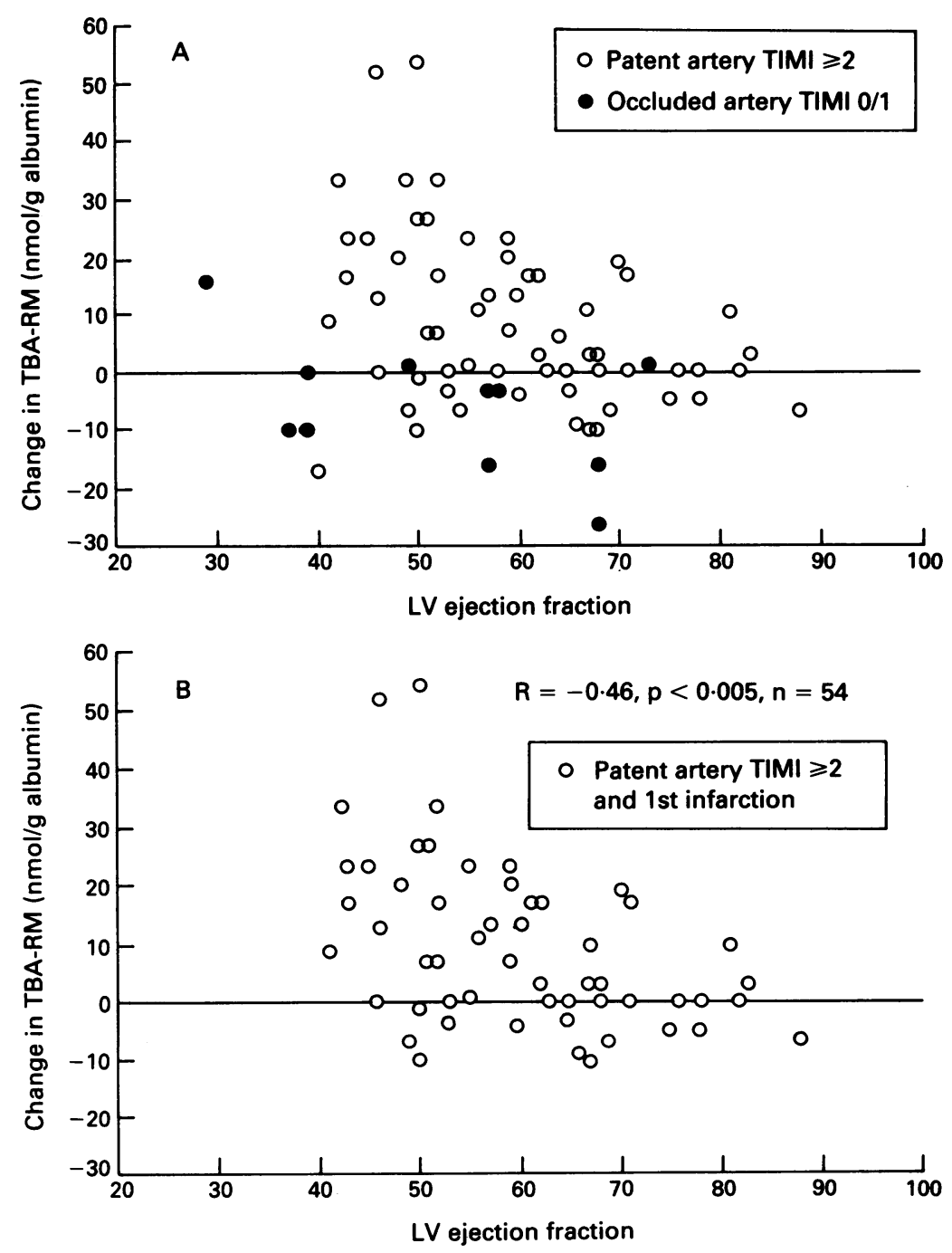

Figure 2 Relation between the increase in TBA-RM associated with thrombolysis and left ventricular ( $L V$ ) ejection fraction: $(A)$ for all subjects studied; $(B)$ for subjects with patent infarct related artery and first myocardial infarct.
BIOCHEMICAL INDICES OF OXIDATIVE STRESS AND FREE RADICAL ACTIVITY

Peripheral venous blood samples were taken immediately before thrombolytic treatment, and one hour after completion of the streptokinase infusion. Samples were withdrawn without tourniquet occlusion into heparinised plastic tubes, and the plasma was separated by centrifugation and frozen to $-20^{\circ} \mathrm{C}$ within half an hour. Samples were stored at $-80^{\circ} \mathrm{C}$ until analysis as one batch.

Lipid peroxidation by free radicals was assessed by measurement of thiobarbituric acid reactive material (TBA-RM) according to the fluorimetric method of Yagi. ${ }^{25} 26$ To allow for any haemodilution due to intravenous fluids, measurements of TBA-RM were expressed with respect to the plasma albumin concentration determined by the bromocresol green method. ${ }^{27}$ Oxidative stress was assessed by measurement of the total plasma concentration of thiol groups by reaction with 5,5-dithio-bis-(2-nitrobenzoic acid) according to the method of Ellman ${ }^{28}$ and performed in duplicate.

\section{ANGIOGRAPHY}

We performed angiography by the Judkins technique in all patients between 18 and 72 hours after thrombolytic treatment. We assessed the patency of the infarct related artery and graded the flow on the Thrombolysis in Myocardial Infarction Trial (TIMI) scale. ${ }^{3}$ Left ventricular function was assessed by ventriculography in the right anterior oblique view with calculation of global left ventricular ejection fraction according to the area length method of Sandler and Dodge. ${ }^{29}$ This analysis was performed by observers blind to the biochemical results.

\section{QRS SCORE}

A second index of infarct size was obtained from the electrocardiographic QRS score as described by Palmeri and colleagues. ${ }^{30}$ The score can vary between zero (for a normal electrocardiogram) and a theoretical maximum of 29, higher values indicating more extensive and deeper $Q$ waves. In practice a score $\geqslant 10$ suggests a severely impaired left ventricle with a global ejection fraction of $30 \%$ or less. ${ }^{30}$ Observers blind to the arteriographic and biochemical measurements used standard 12 lead electrocardiograms recorded at four to 10 days after thrombolysis to assess the scores.

\section{STATISTICAL ANALYSIS}

Variables are given as mean (SD) but in all further analyses non-parametric (distribution free) statistics were used. Unpaired comparisons were made with the Mann-Whitney $U$ test, paired comparisons with the Wilcoxon test, and correlations were examined with the Spearman rank correlation coefficient (R).

\section{Results}

CLINICAL OUTCOME

Patients were clinically stable at the time of 

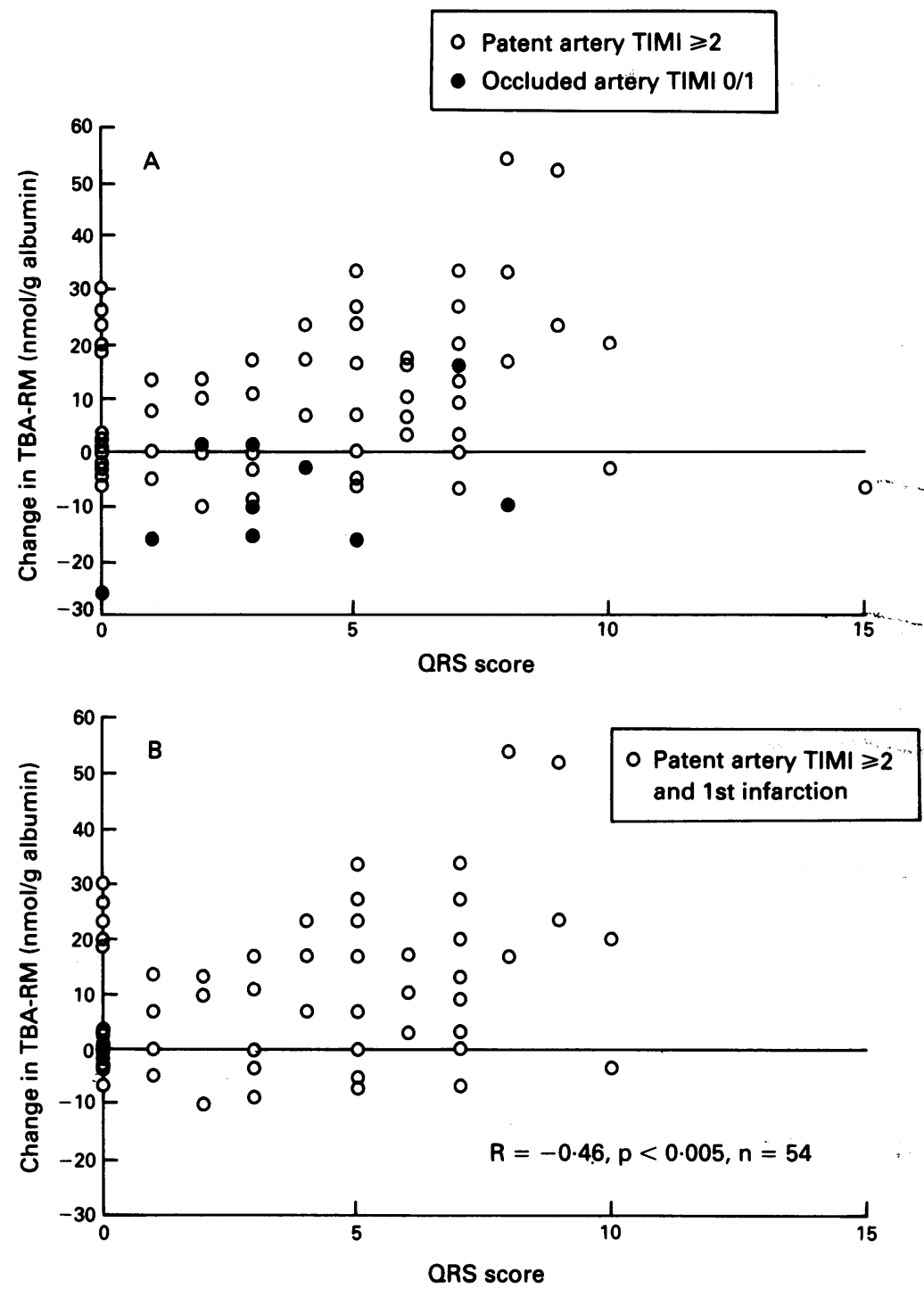

Figure 3 Relation between the increase in TBA-RM associated with thrombolysis and $Q R S$ score: $(A)$ for all subjects studied; $(B)$ for subjects with patent infarct related artery and first myocardial infarct. cant correlation between left ventricular ejection fraction and the QRS score $(R=-0.49$, $\mathrm{p}<0.001$ ).

\section{LIPID PEROXIDATION-THIOBARBITURIC ACID} ASSAY

A wide range of values of TBA-RM was found in the patients before thrombolysis (fig 1A). There was no significant difference in the values before thrombolysis between patients who were found subsequently to have a patent artery and those who had an occluded artery. In the 60 patients subsequently found to have a patent infarct related artery, however, the concentration of TBARM increased after thrombolysis in most cases: the mean change was $+9.2(14.0)$ $\mathrm{nmol} / \mathrm{g}$ albumin. In the 12 patients found subsequently to have an occluded infarct related artery, the concentration of TBA-RM decreased: the mean change was $-7 \cdot 0(11 \cdot 3)$ $\mathrm{nmol} / \mathrm{g}$ albumin. This difference between the groups is significant $(p<0.001)$.

Patients in whom the infarct related artery remained occluded tended to have reduced left ventricular ejection fraction and little change or a fall in TBA-RM (fig 2A). In the 60 patients with a patent infarct related artery there was a significant inverse correlation between the increase in TBA-RM associated with thrombolysis and left ventricular ejection fraction $(R=-0.41, p<0.002)$. The negative correlation between the increase in TBA-RM and left ventricular ejection fraction was slightly strengthened when six patients with previous myocardial infarction were excluded (fig 2B), $(\mathrm{R}=-0.46, \mathrm{p}<0.005, \mathrm{n}=54)$. There was no correlation between left ventricular ejection fraction and the initial concentration of TBA-RM before thrombolysis.

In the 60 patients with a patent infarct related coronary artery there was also a correlation between the increase in TBA-RM associated with thrombolysis and the QRS score (fig 3A), $(R=+0.38, p=0.003)$. This correlation was also strengthened when patients with previous myocardial infarction were excluded (fig 3B), $(R=+0.43, p<0.001$, $\mathrm{n}=54$ )

\section{PLASMA TOTAL THIOLS}

Assay of plasma total thiols was performed for 34 of the 72 patients in the study. All but one of the values before thrombolysis fell within the normal range of $400-600 \mu \mathrm{mol} / 1$. There was no significant difference between the values before thrombolysis in patients who were found subsequently to have a patent infarct related artery and those who had an occluded artery (fig 1B), although the numbers in this part of the study are small. In 30 patients subsequently found to have a patent infarct related artery, however, the concentrations of total plasma thiols tended to decrease $(p<0.02)$, with a mean change of $-12 \cdot 7(31 \cdot 1) \mu \mathrm{mol} / \mathrm{l}$. In four patients subsequently found to have an occluded artery, plasma thiol concentration changed little or increased (NS).

In the 30 patients with a patent infarct in whom the infarct related coronary art was occluded $(4 \cdot 4(2 \cdot 7))$ and those with a patent artery $(4 \cdot 2(3 \cdot 1))$. There was a signifi- 


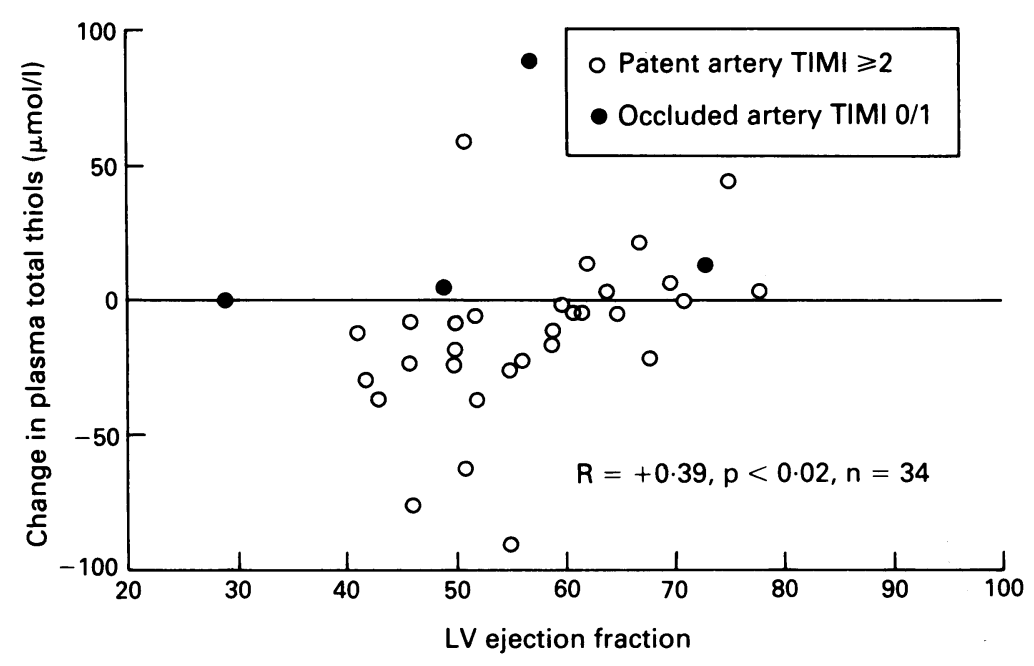

Figure 4 Relation between the decrease in plasma total thiols associated with thrombolysis and left ventricular (LV) ejection fraction for all subjects studied.

related artery there was a significant correlation between the decrease in plasma total thiol concentrations associated with thrombolysis and left ventricular ejection fraction (fig 4), $(\mathrm{R}=+0.39, \mathrm{p}<0.02)$. There was, however, no correlation between this decrease in plasma total thiol concentrations and the QRS score (fig 5), ( $R=-0 \cdot 23$, NS).

A significant inverse correlation between the changes in TBA-RM and in plasma total thiols around the time of thrombolysis $(\mathrm{R}=-0.51, \mathrm{p}<0.002, \mathrm{n}=34)$ was noted.

\section{Discussion}

Thrombolysis improves short-term survival after acute myocardial infarction, ${ }^{1-4}$ but there is less evidence for long-term survival. ${ }^{4}$ The extent of myocardial salvage is likely to be of importance in determining long-term survival as left ventricular ejection fraction is known to be a major determinant of prognosis in a variety of cardiac conditions, ${ }^{31-34}$ specifically after infarction ${ }^{35}$ and in medically treated ischaemic heart disease. ${ }^{36} 37$

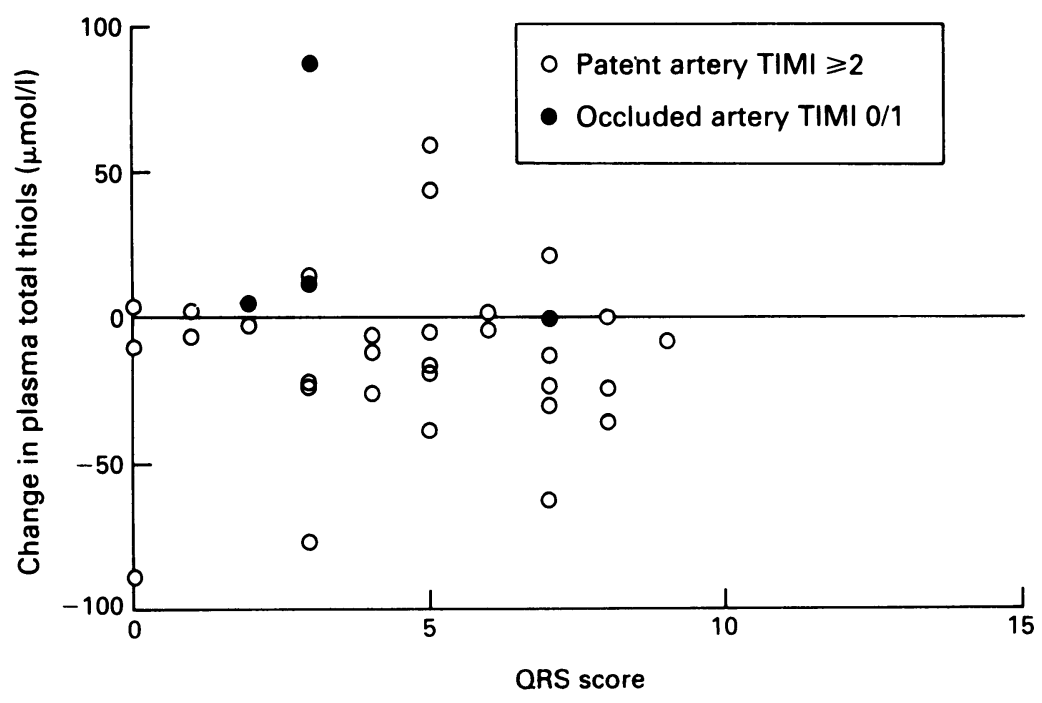

Figure 5 Relation between the decrease in plasma total thiols associated with thrombolysis and QRS score for all subjects studied.
Trials of thrombolytic drugs have shown improvements in left ventricular function compared with controls (table), but in most cases this difference has been small. ${ }^{5}$ It has been postulated that this is partly due to reperfusion injury. ${ }^{19}$ In animal experiments reperfusion reduces infarct size ${ }^{15-17}$ but there are ultrastructural changes and further functional deterioration in the myocardium at the time of reperfusion. ${ }^{17-19}$ It is thought that this reperfusion injury involves oxygen derived free radicals. ${ }^{20-23}$ Electron spin resonance studies show a burst of free radicals shortly after reperfusion. ${ }^{38}{ }^{39}$ Free radical damage to cells after reperfusion can be inferred from measurements of peroxidised lipids and other biochemical markers. ${ }^{40-42}$ Chemicals that limit free radical damage (free radical scavengers) reduce reperfusion injury in animal experiments. ${ }^{43-45}$ Chemical and photochemical systems that generate free radicals cause functional and ultrastructural changes resembling reperfusion injury. ${ }^{38} 4647$

If reperfusion injury occurred in patients, it might reduce the benefits of thrombolytic reperfusion. It is important to maximise myocardial salvage as left ventricular function is a major determinant of prognosis. ${ }^{31-37}$ Unfortunately many of the free radical scavengers that might be used to ameliorate reperfusion injury are expensive, or toxic or both. Large scale trials of scavengers are therefore unlikely until there is evidence that reperfusion injury occurs in patients receiving thrombolytic drugs.

This study provides indirect evidence of oxidative stress related to coronary reperfusion in humans and relates this to left ventricular function. Significant increases in TBA-RM were apparent in blood samples taken just one hour after the completion of streptokinase infusion, "and these increases were associated with patency of the infarct related coronary artery at subsequent arteriography. Increases in circulating TBA-RM after myocardial infarction were first reported in 1983 but their relation to coronary anatomy was not studied. ${ }^{48}$

It is likely that much of this oxidative stress shortly after thrombolysis results from free radical activity, although early activation of neutrophils might also give rise to non-radical oxidants. ${ }^{49}$ The increase in TBA-RM associated with successful thrombolysis might result from lipid peroxidation during the ischaemic period, the lipid peroxides being then washed out by reperfusion; this would also account for the correlation between left ventricular ejection fraction and the amount of the increase in TBA-RM. The alternative explanation is that the lipid peroxidation results from free radicals produced at the time of reperfusion. Electron spin resonance studies show that oxygen free radicals remain at low concentrations during ischaemia but increase abruptly after reperfusion. ${ }^{39}$ Similarly lipid peroxidation does not occur during ischaemia but only during reoxygenation or reperfusion. ${ }^{2050}$ It is therefore likely that the increase in TBA-RM at the time of thrombol- 
ysis in patients with a patent infarct related coronary artery represents free radical production and lipid peroxidation at the time of reperfusion. The extent of this increase correlates with left ventricular function determined by ejection fraction at 18 to 72 hours and by QRS score at four to 10 days, providing further indirect evidence for the existence of reperfusion injury in patients undergoing thrombolysis.

\section{LIMITATIONS OF THE STUDY}

Free radical activity, coronary anatomy, and left ventricular function are more difficult to assess and the time points more restricted in patients than in animal studies; consequently some limitations to our study should be considered. Firstly, direct measurement of oxygen free radicals themselves within the intact myocardium is at present impossible, and so the lipid peroxide content of venous blood was used as an indirect measure. Fortunately lipid peroxides are fairly stable within the circulation, and peripheral venous concentrations accurately reflect coronary sinus concentrations. ${ }^{51}$ Data on the concentrations of plasma total thiols are available in a subgroup of patients in this study, and the decrease in thiol concentration provides supportive evidence of oxidative stress: furthermore there is a significant correlation between the increase in TBA-RM and the decrease in plasma total thiol concentrations at the time of thrombolysis $(R=-0.51$, $\mathrm{p}<0.002$ ).

Secondly, coronary patency was assessed not at the time of blood sampling but at angiography, 18-72 hours later. In some cases there may have been delayed lysis and reperfusion more than two hours after initiation of thrombolysis (that is later than the time of the second blood sample) that would not have been reflected in the blood analyses although at subsequent angiography the patient would have been classified as having a patent infarct related artery. Conversely, an artery that was reperfused early might have reoccluded by the time of angiography. The effect, however, of any random misclassification of patent and occluded cases would be to reduce the apparent correlation between coronary patency and changes in free radical markers around the time of thrombolysis. Had coronary arteriography been performed at the time of thrombolysis as well as between 18 and 72 hours then it is possible that the correlations would have been stronger than those found.

Thirdly, the low in hospital mortality of our group of patients $(1.4 \%)$ raises the possibility that they are not representative of the general body of patients receiving thrombolysis. They were, however, recruited consecutively from admissions to a non-specialist district hospital, and are otherwise typical in terms of age, sex and location of infarction. We are unable to explain their unexpectedly low in hospital mortality.

\section{CLINICAL RELEVANCE-LEFT VENTRICULAR} FUNCTION

The clinical importance of this putative reperfusion injury is suggested by the correlation between the rise in TBA-RM associated with thrombolysis and subsequent left ventricular ejection fraction; although the size of this correlation is small, it is significant $(R=-0.41$, $\mathrm{p}<0.002)$. That this correlation represents free radical mediated reperfusion injury is supported by the correlation between the decrease in plasma total thiol concentration associated with thrombolysis and left ventricular ejection fraction $(R=+0.39, p<0.02)$ (fig 4). The increase in TBA-RM associated with thrombolysis further correlates with the electrocardiographic $Q R S$ score $(R=+0.38$, $\mathrm{p}=0.003$ ) although the changes in plasma thiol concentrations do not.

There are no completely satisfactory measures of infarct size available for clinical use. Serial estimation of creatine kinase concentrations may reflect infarct size, but is dependent upon the rate of washout from injured and necrotic myocardium. ${ }^{52}$ Sophisticated imaging methods such as thallium SPECT (single photo emission computed tomography) seem potentially more accurate but also have their limitations. ${ }^{53}{ }^{54}$ Global left ventricular ejection fraction is not ideal as an index of infarct size, but has the added advantage of strongly predicting subsequent survival. ${ }^{35-37}$ Furthermore left ventricular ejection fraction in our study correlated with the Palmeri QRS score, an independent measure of left ventricular damage. Thus the correlations in the present study are consistent with free radical activity contributing to clinically significant left ventricular dysfunction.

Many variables besides present infarct size influence left ventricular function, including age, previous myocardial infarction, and the timing of reperfusion. When patients with previous infarction are excluded from the analysis, the degree of the correlations of increase in TBA-RM with both left ventricular ejection fraction and QRS score increase (fig 2 and 3) although significance decreases as the number of subjects falls. There are two possible explanations for the fact that the correlation coefficients do not exceed 0.5 . Firstly, it may reflect the imprecise nature of the indices of free radical activity used in the study, the limitations of the indices of left ventricular function and of infarct size, and the difference in time between blood sampling and left ventriculography. Secondly, it may be that much of the variability in left ventricular ejection fraction relates to other factors. Thus although free radical activity seems to contribute to left ventricular dysfunction and may be a target for treatment, other factors such as the previous state of the left ventricle and the size of the ischaemic area at risk may be more important.

In conclusion, our study provides indirect evidence that reperfusion injury may contribute to left ventricular dysfunction in patients in whom thrombolysis has been successful. The importance of reperfusion injury 
requires further quantitative assessment. The present study evaluated left ventricular function early (18 to 72 hours) after thrombolysis and has not assessed whether this dysfunction represents reversible myocardial stunning or permanent dysfunction. Nevertheless, adjuvant treatment with free radical scavenging drugs in patients undergoing thrombolysis may improve the myocardial salvage achieved by reperfusion. Some potential free radical scavenging agents are both cheap and relatively non-toxic, such as allopurinol, which has recently been reported to improve left ventricular function after coronary artery bypass surgery. ${ }^{55}$ Clinical trials of selected free radical scavenging drugs in patients receiving thrombolysis would be of great interest.

1 Yusuf S, Collins R, Peto R, Furberg C, Stampfer MJ, Goldhaber SZ, Hennekens $\mathrm{CH}$. Intravenous and intracoronary fibrinolytic therapy in acute myocardial infarction: overview of results on mortality, reinfarction and side effects from 33 randomised controlled trials. Eur Heart $\mathcal{F} 1985 ; 6: 556-85$.

2 Gruppo Italiano per lo Studio della Streptochinas; nell'Infarto Miocardico (GISSI). Effectiveness of intra-
venous thrombolytic treatment in acute myocardial venous thrombolytic treatment in
infarction. Lancet $1986 ; 1: 397-402$.

3 Chesebro JH, Knatterud G, Roberts R, Borer J, Cohen LS, Dodge HT, et al. Thrombolysis in myocardial infarction (TIMI) trial, phase I: a comparison between intravenous tissue plasminogen activator and intravenous streptokinase. Circulation 1987;76:142-54

4 Second International Study of Infarct Survival (ISIS-2) study group. Randomised trial of intravenous streptokinase, oral aspirin, both, or neither among 17187 cases of suspected acute myocardial infarction: ISIS-2. Lancet 1988;2:349-60.

5 Van de Werf F. Discrepancies between the effects of coronary reperfusion on survival and left ventricular function. Lancet 1989;1:1367-8.

6 White HD, Norris RM, Brown MA, Takayama M Maslowski A, Bass NM, et al. Effect of intravenous streptokinase on left ventricular function and early survival after acute myocardial infarction. $N$ Engl $\mathfrak{f} \mathrm{Med}$ 1987;317:850-5.

7 Schreiber TL, Miller DH, Silvasi DA, Moses JW, Borer JS. Randomised double-blind trial of intravenous streptokinase for acute myocardial infarction. $A m \mathcal{f}$ Cardiol 1986;58:47-52.

8 Kennedy JW, Martin GV, Davis KB et al. The Western Washington intravenous streptokinase in acute myocardial infarction randomised trial. Circulation 1988;77: dial infa 52 .

9 Olson HG, Butman SM, Piters KM, Gardin JM, Lyons KP, Jones L, Chilazi G, Kumar A, Colombo A. A randomised controlled trial of intravenous streptokinase in acute myocardial infarction. Am Heart $\mathcal{F}$ 1986;111: 1021-9.

10 Intravenous streptokinase in acute myocardial infarction (ISAM) study group. Prospective trial of intravenous streptokinase in acute myocardial infarction: mortality,
morbidity, and infarct size at 21 days. $N$ Engl $7 \mathrm{Med}$ 1986;314:1465-71.

11 O'Rourke M, Baron D, Keogh A, and The Sydney and Auckland Co-Operative Group for the Study of Thrombolysis in Acute Coronary Occlusion (TICO). sion. Circulation 1988;77:1311-5.

12 Guerci $A D$, Gerstenblith G, Brinker JA, Chandra NC Gottlieb SC, Bahr RD, et al. A randomised trial of intradissue plasminogen activator for acute myocar dial infarction with subsequent randomisation to elective coronary angioplasty. $N$ Engl $f$ Med 1987; 317:1613-8.

13. National Heart Foundation of Australia Coronary Thrombolysis Group. Coronary thrombolysis and myocardial salvage by tissue plasminogen activator given up to 4 hours after onset of myocardial infarction. Lancet 1988;i:203-8.

14 Van de Werf F, Arnold AER and The European CoOperative Study Group for recombinant tissue plasminogen activator (rt-PA). Effect of intravenous tissue minogen activator (rt-PA). Effect of intravenous tissue plasminogen activator on infarct size, left ventricular function, and survival in patients with

15 Mathur VS, Guinn GA, Burris WH III. Maximal revascularisation (reperfusion) in intact conscious dogs after 2 to 5 hours of coronary occlusion. $\mathrm{Am} \mathscr{f}$ Cardio 1975;36:252-61.

16 Reimer KA, Lowe JE, Rasmussen MM, Jennings RB. The "wavefront phenomenon" of ischaemic cell death. I.
Myocardial infarct size versus duration of coronary occlusion in dogs. Circulation 1977;56:786-94.

17 Jennings RB, Reimer KA. Factors involved in salvaging ischaemic myocardium - effect of reperfusion of arterial blood. Circulation 1983;68(suppl I): I.25-36.

18 Braunwald E, Kloner RA. The stunned myocardium prolonged post-ischaemic ventricular dysfunction. Circulation 1982;66:1146-9.

19 Braunwald E, Kloner RA. Myocardial reperfusion: a double-edge sword. 7 Clin Invest 1985;76:1713-9.

20 Guarnieri C, Flamigini F, Caldarera CM. Role of oxygen in the cellular damage induced by reoxygenation of hypoxic heart. $f$ Mol Cell Cardiol 1980;12:797-808.

21 Hammond B, Hess ML. The oxygen-free radical system potential mediator of myocardial injury. $f \mathrm{Am}$ Coll Cardiol 1985;6:215-20.

22 Burrell CJ, Blake DR. Reactive oxygen metabolites and the human myocardium. Br Heart f 1989;61:4-8.

23 Davies SW. Free radicals and myocardial disease - studies in patients. In: Rice-Evans C, ed. Free radicals, diseased states, and anti-radical interventions. London: Richelieu Press, 1989:97-115.

24 Davies SW, Ranjadayalan K, Wickens DG, Dormandy TL, Timmis AD. Lipid peroxidation associated with successful thrombolysis. Lancet 1990;335:741-3.

25 Yagi K. A simple fluorimetric assay for lipoperoxide in blood plasma. Biochem Med 1976;15:212-6.

26 Yagi K. Assay for serum lipid peroxide level and its clinical significance. In: K Yagi, ed. Lipid peroxides in biology and medicine. New York: Academic Press, 1982:223-41.

27 Rodkey FL. Direct spectrophotometric determination of albumin in human serum. Clin Chem 1965;1:478-87.

28 Ellman GL. Tissue sulphydryl groups. Arch Biochem Biophys 1957;82:70-7.

29 Sandler H, Dodge HT. The use of single plane angiocardiograms for the calculation of left ventricular volume in man. Am Heart f 1968;75:325-34

30 Palmeri ST, Harrison DG, Cobb FR, Morris KG, Harrell FE, Ideker RE, Selvester RH, Wagner GS. A QRS scoring system for assessing left ventricular function after myocardial infarction. N Engl $\mathcal{f}$ Med 1982;306:4-9.

31 Goodwin JF. Congestive and hypertrophic cardiomyopathy: a decade of study. Lancet 1970;1:731-9.

32 Borer JS, Rosing DR, Miller RH, Stark RM, Kent KM, Bacharach SL, et al. Natural history of left ventricula function during 1 year after acute myocardial infarction: comparison with clinical, electrocardiographic, and biochemical determinations. Am $\mathcal{F}$ Cardiol 1980;46:1-12.

33 Borow K, Green LH, Mann T, Sloss LJ, Braunwald E, Collins JJ, et al. End-systolic volume as a predictor of postoperative left ventricular performance in volume overload from valvular regurgitation. Am $f$ Med 1980; 68:655-63.

34 Fuster V, Gersh BJ, Guiliani ER, Tajik AJ, Brandenburg RO, Frye RL. The natural history of dilated cardiomyopathy. Am f Cardiol 1981;47:525-31.

35 White HD, Norris RM, Brown MH, Brandt PWT, Whitlock RML, Wild CJ. Left ventricular end-systolic volume is the major determinant of survival after recov ery from myocardial infarction. Circulation 1987;76 44-51.

36 Vlietstra RE, Frye RL, Kronmal RA, Sim DA, Tristani FE, Killip T III, and participants in the Coronary Artery Surgery Study. Risk factors and angiographic coronary artery disease: a report from the coronary artery surgery study (CASS). Circulation 1980;62: 254-61.

37 Brunelli C, Cristofani R, L'Abbate A, and OD1 Study Group. Long-term survival in medically treated patients with ischaemic heart disease and prognostic importance of clinical and electrocardiographic data. Eur Heart $\mathfrak{F}$ 1989;10:292-303.

38 Hess ML, Okabe E, Kontos HA. Proton and free oxygen radical interaction with the calcium transport system of cardiac sarcoplasmic reticulum. F Mol Cell Cardio 1981;13:767-72.

39 Garlick PB, Davies MJ, Hearse DJ, Slater TF. Direct detection of free radicals in the reperfused rat heart using electron spin resonance spectroscopy. Circ Res 1987;61:757-60.

40 Meerson FZ, Adikaliev NA, Golubeva LY. Prevention of hypoxic heart injury by an antioxidant of the hydroxyhypoxic heart injury by an antioxidant of the hydroxypyridine class. Byull Eksp Biol Med 1981;92:281-3. (Russian article with English abstract; tra

41 Ferreira R, Llesuy S, Mieli J, Scordo D, Hourquebie H, Motteni L, et al. Assessment of myocardial oxidative stress in patients after myocardial revascularisation. $A m$ Heart $\mathcal{F} 1988 ; 115: 307-12$.

42 Del Nido PJ, Mickle DAG, Wilson GJ, Benson LN, Coles JG, Trusler GA, Williams WG. Evidence of myocardial free radical injury during elective repair of tetralogy of Fallot. Circulation 1987;76(suppl II):174-9.

43 Guarnieri C, Ferrari R, Visioli O, Caldarera CM, Nayler WG. Effect of alphatocopherol on hypoxic-perfused and reoxygenated rabbit heart muscle. $\mathcal{F} \mathrm{Mol}$ Cell Cardiol 1978;10:893-906.

44 Forman MB, Puett DW, Cates CU, McCroskey DE Bechman JK, Greene HL, Virmani R. Glutathione redox pathway and reperfusion injury. Effect of $\mathrm{N}$-acetyl redox pathway and reperfusion injury. Effect of $\mathrm{N}$-acetyl
cysteine on infarct size and ventricular function. cysteine on infarct size

45 Westlin W, Mallain K. Does captopril attenuate reperfusion-induced myocardial dysfunction by scavenging free radicals? Circulation 1988;77(suppl I):I.30-9. 
46 Hearse DJ, Tosaki A. Free radicals and calcium: simultaneous interacting triggers as determinants of vulnerability to reperfusion -arrhythmias in the rat heart. $f \mathrm{Mol} \mathrm{Cell}$ ty to reperfusion -arrhyth
Cardiol $1988 ; 20: 213-23$.

47 Kusama Y, Bernier M, Hearse DJ. Singlet oxygeninduced arrhythmias: light-response characteristics for photosensitisation by rose bengal [abstract 1830]. Circulation 1988;78(suppl II):2-459.

48 Dousset J-C, Trouilh M, Foglietti M-J. Plasma malonaldehyde levels during myocardial infarction. Clin Chim Acta 1983;129:319-22.

49 Ranjayalan K, Umachandran V, Davies SW, Syndercombe-Court D, Gutteridge CN, Timmis AD. Thrombolytic treatment in acute myocardial infarction: neutrophil activation, peripheral neutrophil responses, and myocardial injury. Br Heart $\mathcal{F}$ 1991;66:10-4.

50 Barsachi R, Pelosi G, Camici P, Bonaldo L, Malorino M, Ursini $F$. Glutathione depletion increases chemiluminescence and lipid peroxidation in the heart. Biochem Biophys Acta 1984;804:356-60.

51 Davies SW, Underwood SM, Wickens D, Feneck RO,
Walesby RK, Dormandy TL. Systemic pattern of free radical generation during cardiopulmonary bypass. $\mathrm{Br}$ Heart $f$ 1990;64:236-40.

52 Ong L, Coromilas J, Zimmerman JM, Green S, Padmanabhan V, Reiser $\mathrm{P}$, et al. A physiologically based model of creatine kinase-MB release in reperfusion of acute myocardial infarction. Am f Cardiol 1989;64:11-5. 53 Bassand J-P, Machecourt J, Cassagnes J, Augenot T, Lusson R, Borel E, et al, for the APSIM study investigators. Multicenter trial of intravenous anisoylated plasminogen streptokinase activator complex (APSAC) in acute myocardial infarction: effects on infarct size and left ventricular function. $\mathcal{F} \mathrm{Am}$ Coll Cardiol 1989;13 988-97.

54 Beller GA. Noninvasive assessment of myocardial salvage after coronary reperfusion: a perpetual quest of nuclear cardiology. [Editorial]. $\mathcal{f} \mathrm{Am}$ Coll Cardiol 1989;14: 874-6.

55 Johnson WD, Kayser KL, Brenowitz JB, Saedi SF. A randomised controlled trial of allopurinol in coronary bypass surgery. Am Heart $\mathcal{F}$ 1991;121:20-4. 